\title{
Investigating the Effects of Formetanate Hydrochloride on Human Hemoglobin by Spectroscopic Analysis and Molecular Docking Modeling
}

Ali Khatibi Sharifiyeh (PhD) Department of Biotechnology, Faculty of Biological Sciences, Alzahra University, Sheikh Bahai Square, Tehran, Iran

Elmira Rezaei Pajouhesh (MSc Student)

Department of Biotechnology, Faculty of Biological Sciences, Alzahra University, Tehran, Iran

Zahra Moosavi-Nejad (PhD) Department of Biotechnology, Faculty of Biological Sciences, Alzahra University, Tehran, Iran

Corresponding author: Ali Khatibi Sharifiyeh

Tel: +98-9124970501

Email: khatibi@alzahra.ac.ir

Address: Department of

biotechnology, Faculty of biological sciences, Alzahra University, Sheikh Bahai Square, Tehran, Iran

Received: 21 Jan 2019

Revised: 03 Feb 2019

Accepted: 05 Feb 2019

\section{cc) (i) (-)}

This work is licensed under a Creative Commons Attribution 4.0 License.
ABSTRACT

Background and 0bjectives: Formetanate hydrochloride is an effective insecticide and acaricide, which is frequently used in citrus gardens. Given its high toxicity, it is necessary to evaluate effects of this insecticide on living factors. In this study, we investigate effects of formetanate hydrochloride on human hemoglobin using spectroscopic analysis and molecular docking modeling.

Methods: Effects of formetanate hydrochloride on human hemoglobin were investigated using molecular docking technique and thermodynamic and spectrophotometric methods such as normal and synchronous fluorescence spectroscopy, IV-Vis absorption spectroscopy and circular dichroism.

Results: Decrement of the soret band without any significant shift proved that the insecticide could penetrate into the heme pocket and directly interact with the porphyrin ring. Results obtained from the intrinsic fluorescence spectroscopy and heme degradation study at 321 and $460 \mathrm{~nm}$ indicated that formetanate hydrochloride could potentially destroy the heme prosthetic group and eliminate its filtering effect, which results in fluorescence enhancement. The fluorescence study demonstrated a competitive behavior between hydrophobic probe ANS and formetanate hydrochloride for binding to the hemoglobin hydrophobic patches. Results of circular dichroism and synchronous fluorescence spectroscopy confirmed the structural change and polarity alteration around aromatic fluorophores.

Conclusion: 0ur findings elucidate that the binding of formetanate hydrochloride to hemoglobin through the heme pocket is energetically much more favorable compared to binding to the hydrophobic central cavity. In addition, formetanate hydrochloride can cause conformational changes in the human hemoglobin and the competitive behavior of this insecticide for the oxygen site can subsequently reduce the oxy form of hemoglobin.

Keywords: Hemoglobin, Insecticides, Protein Degradation, Fluorescence.

This paper should be cited as: Khatibi Sharifiyeh A, Rezaei Pajouhesh E, Moosavi-Nejad Z [Investigating the Effects of Formetanate Hydrochloride on Human Hemoglobin by Spectroscopic Analysis and Molecular Docking Modelinal. mliaoums. 2019; 13(4):34-41 


\section{INTRODUCTION}

Hemoglobin $(\mathrm{Hb})$ plays a crucial role in the vascular system of human beings as a carrier of oxygen. According to its atomic structure, hemoglobin is a tetrameric protein composed of two identical $\alpha$ and two identical $\beta$ chains each consisting of 141 and 146 amino acid residues, respectively that are held together by non-covalent bonds. They share a common tertiary structure that makes the globin part of each subunit to form a hydrophobic pocket that envelopes the heme prosthetic group. Approximately $75 \%$ of the globin chains are found in $\alpha$-helical structure (1).

The $89^{\text {th }}$ residue in the $\alpha$ chains and the $92^{\text {nd }}$ residue in the $\beta$ chains are called proximal histidine (his F8), which is attached to a ferrous iron atom through its imidazole nitrogen and links the globin part to prosthetic group (2). In general, the prosthetic heme group plays a key role in cooperative interaction between hemoglobin and its natural ligands (3). Hence, structural properties of $\mathrm{Hb}$ makes it a vital factor for electron and proton transport to different parts of body, regulation of blood $\mathrm{pH}$, oxygen and carbon dioxide transport (4). Formetanate hydrochloride [m(((dimethylamino)methylene)-

amino)phenylmethylcarbamate hydrochloride] is an effective insecticide and acaricide which is frequently used in citrus gardens. This compound consists of two functional groups: carbamate moiety that acts as an acetylcholinesterase inhibitor, which primarily affects the peripheral somatic and autonomic nervous systems; and formamidine moiety that inhibits the neurotransmitter octopamine during a competitive process that stimulates insects' nerves, leading to convulsion $(5,6)$. Formetanate hydrochloride is considered an environmental pollutant with adverse effects on target and non-target creatures. Due to its ionic structure, high water solubility $(>50 \mathrm{~g}$ $100 \mathrm{~mL}^{-1}$ ) and poor soil absorption, this insecticide is able to flow on the agricultural fields and contaminate groundwater and surface water. Furthermore, it is resistance against hydrolysis in natural water, which increases its persistence in the environment. Exposure to insecticides, either directly (oral, inhalation or contact with eyes and skin) or indirectly (from agricultural products to body), subsequently threaten the life of creatures, especially human beings. Similar to other carbamate insecticides, formetanate hydrochloride is widely used around the globe. Considering its high toxicity (LG50 (rat) = $14.8 \mathrm{mg} \cdot \mathrm{kg}^{-1}$ ), it is essential to investigate effects of this compound on living factors (7). In this study, we investigate effects of this insecticide on human $\mathrm{Hb}$.

\section{MATERIALS AND METHODS}

Human $\mathrm{Hb}$ and formetanate hydrochloride were purchased from Sigma Aldrich Company. Tris base was obtained from S.R.L (India) and $\mathrm{NaCl}$ and $\mathrm{HCl}$ were from Merck (Germany). All buffers (Tris [0.05 $\mathrm{M}]$ and TBS [0.05 $\mathrm{M}$ tris $+0.15 \mathrm{M} \mathrm{NaCl}]$ ) were prepared using double distilled water in $\mathrm{pH}=7.4$. Stock solution of human $\mathrm{Hb}(100$ $\mu \mathrm{M})$ was diluted to $3 \mu \mathrm{M}$ for spectroscopic studies. A concentration range of 7.5 to 255 $\mu \mathrm{M}$ was prepared from the stock solution of formetanate $(1.5 \mathrm{mM})$. After adding the prepared concentrations of formetanate hydrochloride to $\mathrm{Hb}$ samples, UV-Vis spectrum was recorded at 200 to $500 \mathrm{~nm}$ and $25{ }^{\circ} \mathrm{C}$ using a Uv-Vis spectrophotometer (Carry 100, Varian Co., Australia) equipped with $1 \mathrm{~cm}$ quartz cells. Uv-Vis absorption measurement is an applicable technique for investigating conformational changes and complex formation (8).

Protein thermal denaturation curvature gives information about structural stability of proteins against increasing course of temperature that can be described by the Tm value. In fact, $\mathrm{Tm}$ is a temperature where the protein is semi-folded; therefore, more stable proteins have higher Tm values $(9,10)$. By studying protein thermal stability at $280 \mathrm{~nm}$ in an incremental range of temperature from $25^{\circ} \mathrm{C}$ to $75{ }^{\circ} \mathrm{C}$ at a rate of $2^{\circ} \mathrm{c} \mathrm{min}^{-1}$, we determined the protein conformational change and subsequently its Tm value using the Carry 100 bio spectrophotometer (Varian Co., Australia).

Protein aggregation potential upon addition of formetanate hydrochloride was assessed by recording the increasing absorption at $360 \mathrm{~nm}$ for 1000 seconds at a temperature of $68{ }^{\circ} \mathrm{C}$. Moreover, intrinsic fluorescence spectra were recorded after adding different concentrations of formetanate hydrochloride to $\mathrm{Hb}$ samples using a spectrofluorometer (Carry eclipse, Varian Co., Australia) at $25{ }^{\circ} \mathrm{C}, 33{ }^{\circ} \mathrm{C}$ and $37^{\circ} \mathrm{C}$ from 290 to $450 \mathrm{~nm}$ while excitation wavelength was fixed at $280 \mathrm{~nm}$ and excitation 
and emission slits were 5 and $10 \mathrm{~nm}$, respectively. To detect the insecticide-induce heme degradation products, all samples were excited at 321 and $460 \mathrm{~nm}$ and their emission spectra were collected from 345 to $600 \mathrm{~nm}$ and 470 to $700 \mathrm{~nm}$, respectively. To identify the ANS competitive binding to $\mathrm{Hb}$ hydrophobic patches in the presence of formetanate hydrochloride, $250 \mu \mathrm{M}$ ANS was added to the samples containing $3 \mu \mathrm{M} \mathrm{Hb}$ and different concentrations of the insecticide. Then, emission spectra were recorded at $25{ }^{\circ} \mathrm{C}$ from 430 to $580 \mathrm{~nm}$ at the excitation wavelength of $380 \mathrm{~nm}$.

Far UV-circular dichroism (CD) spectra of $\mathrm{Hb}$ in the absence and presence of formetanate hydrochloride $(5-40 \mu \mathrm{M})$ were recorded from 195 to $200 \mathrm{~nm}$ using a CD spectrofluorimeter (215, Aviv Co., USA) at $25^{\circ} \mathrm{C}$ and $\mathrm{pH}=7.4$.

Generally, like quenching phenomenon, fluorescence enhancement may result from ground-state complex formation, excited state reaction, energy transfer and collisional processes. The Stern-Volmer equation can describe how a ligand interacts with a macromolecule and cause fluorescence quenching or enhancement. In this regard, fluorescence enhancement data were investigated using the following equation: $F_{0} / F$ $=1-\mathrm{K}_{\mathrm{D}}[\mathrm{E}]=1-\mathrm{k}_{\mathrm{B}} \mathrm{G} 0[\mathrm{E}]$ (1). According to the Stern-Volmer equation, F0 and $\mathrm{F}$ are fluorescence intensities in the absence and presence of enhancer ligand (formetanate hydrochloride), $\mathrm{K}_{\mathrm{D}}$ is the dynamic constant of fluorescence enhancement, $\mathrm{k}_{\mathrm{B}}$ is the rate constant of biomolecular fluorescence enhancement, $\mathrm{G} 0$ is the average lifespan of macromolecule in the absence of enhancer and $[\mathrm{E}]$ is the molar concentration of the enhancer molecule. In case of fluorescence enhancement following ligand-macromolecule interaction through equivalent binding sites, the binding parameters can be calculated using the following equation: $\log \left(F-F_{0}\right) / F=\log K_{b}+$ $n \log$ [E] (2). In this equation, $F$ and $F_{0}$ are the maximum fluorescence intensities in the absence and presence of enhancer ligand [E], $\mathrm{K}_{\mathrm{b}}$ is the binding constant and $\mathrm{n}$ is the number of binding sites. By plotting $\log \left(\mathrm{F}-\mathrm{F}_{0}\right) / \mathrm{F}$ versus $\log [E], n$ and $K_{b}$ values can be obtained from the slope and intercept, respectively.

Interaction between small molecules and biological macromolecules can occur through four classical non-covalent forces: hydrogen, electrostatic, hydrophobic and van der Waals bonds (11). The type of binding forces between formetanate hydrochloride and $\mathrm{Hb}$ can be determined by calculating the temperature-dependent thermodynamic parameters: enthalpy change, entropy change and Gibbs free energy change. If the $\Delta \mathrm{H}^{\circ}$ (enthalpy change) gradually changes over the temperature range studied, both $\Delta \mathrm{H}^{\circ}$ and $\Delta \mathrm{S}^{\circ}$ (entropy change) values can be obtained from the van't Hoff equation. By graphing lnk versus $1 / \mathrm{T}$ as reciprocal absolute temperature, based on the van't Hoff equation, thermodynamic parameters, such as enthalpy and entropy can be calculated: $\operatorname{lnK}_{\mathrm{a}}=-$ $\left(\Delta \mathrm{H}^{\circ} / \mathrm{RT}\right)+\left(\Delta \mathrm{S}^{\circ} / \mathrm{R}\right)$, where $\mathrm{K}_{\mathrm{a}}$ and $\mathrm{R}$ are the association constant and gas constant, respectively (3). To elucidate the Gibbs free energy change of reaction, $\Delta \mathrm{H}^{\circ}$ and $\Delta \mathrm{S}^{\circ}$ values were placed in the following equation: $\Delta \mathrm{G}^{\circ}=\Delta \mathrm{H}^{\circ}-\left(\mathrm{T} \Delta \mathrm{S}^{\circ}\right)(4)$.

Molecular docking is an effective computational method used to forestall the probable binding site of drugs or ligands onto a protein. It can help validate the experimental results. To identify the most favorable ligand binding sites on $\mathrm{Hb}$, we carried out molecular docking using the Molegro Virtual Docker software (MVD 2008 version 3.2.1). The crystal structure of human $\mathrm{Hb}$ was downloaded from the Protein Data Bank (PDB code: 1GZX) and the atomic structure of formetanate hydrochloride was designed using PRODRG server. After minimizing the energy of the system ( $\mathrm{Hb}$ and formetanate hydrochloride), docking process was performed by the software.

Figure 1- Absorption spectra of $\mathrm{Hb}$ and formetanate- $\mathrm{Hb}$ complex. Concentration of $\mathrm{Hb}$ was $3 \mu \mathrm{M}$. Formetanate concentrations in the formatanate-Hb complex were 30, 90, 120, 150 and $255 \mu \mathrm{M}$.

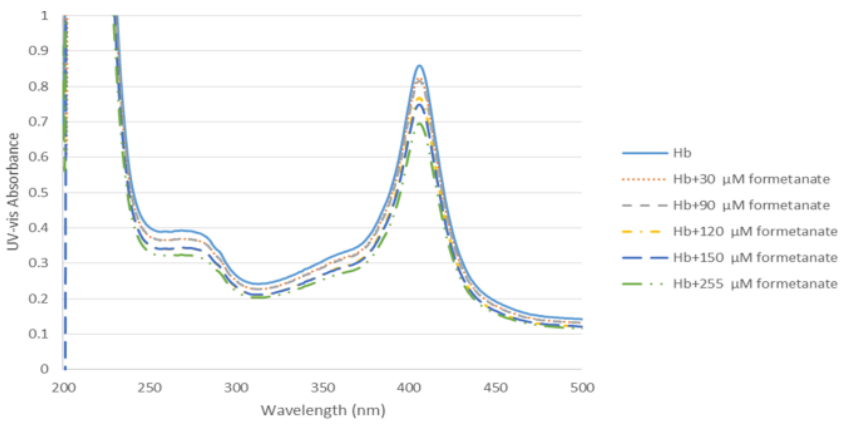


Figure 2- Absorption spectra of $\mathrm{Hb}$ at 500-600 $\mathrm{nm}$ related to oxy-Hb. Concentration of $\mathrm{Hb}$ was 3 uM. Formetanate concentrations in the formatanate-Hb comblex were 30.90. 120.150 and 255

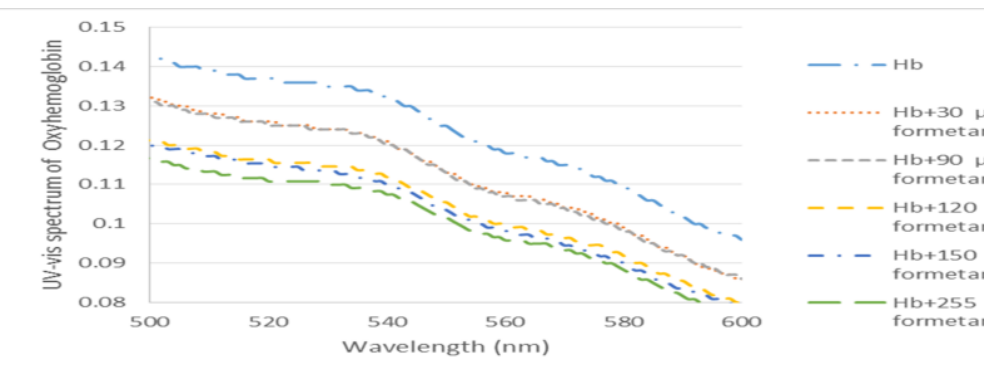

Figure 3- Thermal denaturation profile of $\mathrm{Hb}$ with increasing concentrations of formetanate at $\mathrm{pH} 7.4$ and $280 \mathrm{~nm}$. Formetanate concentrations in the formatanate-Hb complex were $45,52.5$ and $60 \mu \mathrm{M}$.

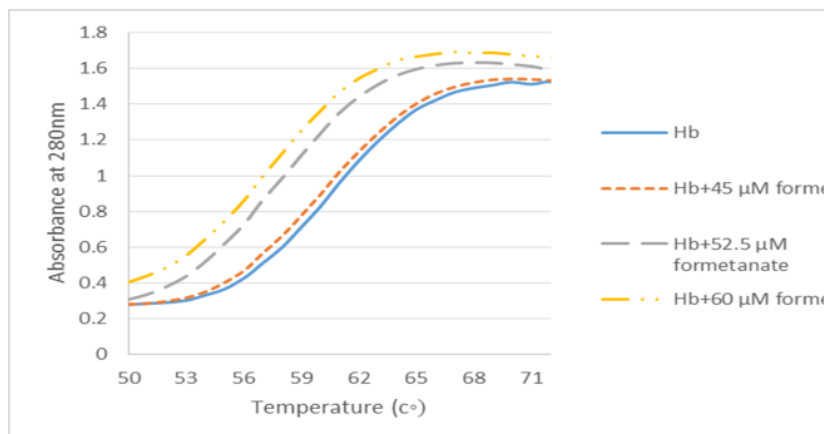

Figure 4- Aggregation potential of $\mathrm{Hb}$ in the absence and presence of formetanate at concentrations of $45,52.5$ and $120 \mu \mathrm{M}$ and $\mathrm{pH}$ 7.4.

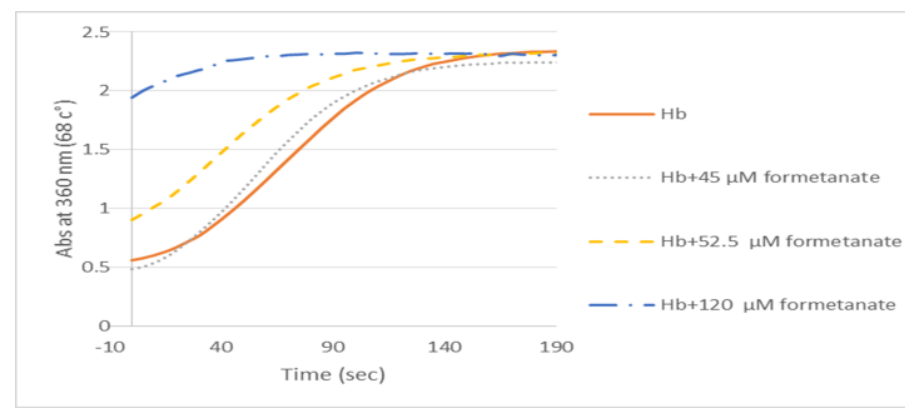

\section{RESULTS}

As shown in figure 1, increasing the concentration of formetanate hydrochloride caused hypochromocity in all three main parts of the $\mathrm{Hb}$ absorption spectra without any significant shift. The first region (at $285 \mathrm{~nm}$ ) was related to globin absorption. The second region (Soret band at $406 \mathrm{~nm}$ ) was related to heme iron porphyrin complex absorption, and the third region (Q band at 550-600 $\mathrm{nm}$ ) was related to the oxy- and deoxy-forms of heme. However, no shift was observed towards lower or higher wavelengths. Furthermore, diminishing the characteristic peak at $406 \mathrm{~nm}$ without any displacement indicated that formetanate hydrochlorid penetrated into the heme pocket and directly interacted with the heme group without exposing it to the solvent
, Tm (midpoint transition temperature) was obtained from thermal denaturation curves at a fixed wavelength of $280 \mathrm{~nm}$. As shown in figure 3 , with gradual addition of formetanate hydrochloride, Tm values decreased (by $4{ }^{\circ} \mathrm{C}$ in the sample with higher concentrations of insecticide). Increase in concentration of formetanate hydrochloride reduced the lag phase and increased the slope of the logarithmic phase (Figure 4).

Fluorescence intensity measurement gives useful information about protein conformational changes and complex formation. We observed that increasing the concentration of formetanate hydrochloride to 
the $\mathrm{Hb}$ solution introduced a significant red shift in intrinsic fluorescence intensity of free protein. Two different heme degradation products exhibit fluorescence emission at the wavelengths of 465 and $550 \mathrm{~nm}$ after excitation at 321 and $460 \mathrm{~nm}$, respectively. As shown in figures 5 and 6 , binding of formetanate hydrochloride to $\mathrm{Hb}$ induced heme degradation.

This is also evident from the increase in fluorescence intensity at $465 \mathrm{~nm}$ and $550 \mathrm{~nm}$.

Figure 5- Effect of formetanate on fluorescence spectrum of $\mathrm{Hb}(\mathrm{T}=295 \mathrm{~K}, \mathrm{pH} 7.40$, $\lambda \mathrm{ex}=280 \mathrm{~nm})$.

Concentration of $\mathrm{Hb}$ was $3 \mu \mathrm{M}$. Formetanate concentrations in the formatanate-Hb complex were 7.5, $22.5,37,52.5,120,180$ and $255 \mu \mathrm{M}$.

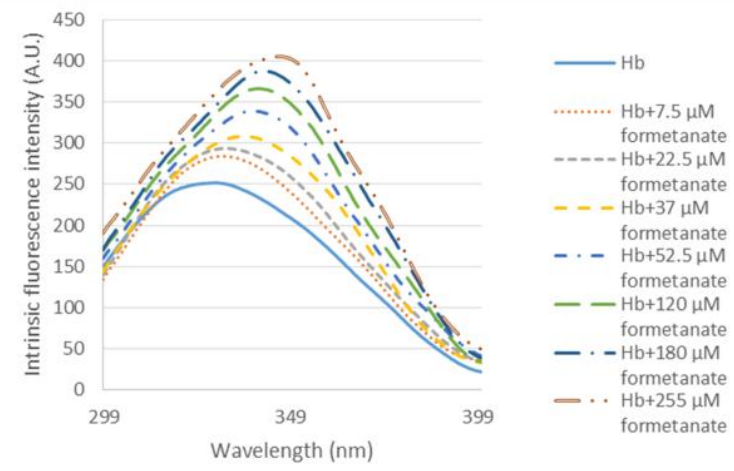

Table 1- Content of $\mathrm{Hb}$ secondary structures before and after the addition of formetanate

\begin{tabular}{|c|c|c|c|c|c|c|}
\hline $\begin{array}{l}\text { Secondary } \\
\text { structures }\end{array}$ & $\mathbf{H b}$ & $\begin{array}{c}\mathrm{Hb}+5.7 \mu \mathrm{M} \\
\text { Formetanate }\end{array}$ & $\begin{array}{c}\mathrm{Hb}+5 / 22 \mu \mathrm{M} \\
\text { Formetanate }\end{array}$ & $\begin{array}{c}\mathrm{Hb}+45 \mu \mathrm{M} \\
\text { Formetanate }\end{array}$ & $\begin{array}{l}\mathrm{Hb}+52.5 \mu \mathrm{M} \\
\text { Formetanate }\end{array}$ & $\begin{array}{c}\mathrm{Hb}+60 \mu \mathrm{M} \\
\text { Formetanate }\end{array}$ \\
\hline Alpha helix & $44.37 \%$ & $36.28 \%$ & $35.31 \%$ & $30.81 \%$ & $26.86 \%$ & $26.55 \%$ \\
\hline Antiparallel & $3.94 \%$ & $5.14 \%$ & $5.19 \%$ & $7.25 \%$ & $8.55 \%$ & $8.39 \%$ \\
\hline Parallel & $6.9 \%$ & $8.28 \%$ & $8.49 \%$ & $9.23 \%$ & $10.02 \%$ & $10.12 \%$ \\
\hline Beta turns & $14.29 \%$ & $14.76 \%$ & $14.63 \%$ & $15.55 \%$ & $15.73 \%$ & $15.6 \%$ \\
\hline Random coils & $30.47 \%$ & $35.52 \%$ & $36.44 \%$ & $37.13 \%$ & $38.82 \%$ & $39.32 \%$ \\
\hline
\end{tabular}

Table 2- Dynamic and bimolecular enhancement constants for the $\mathrm{Hb}$ - formetanate interaction at different temperatures

\begin{tabular}{cccc}
\hline$T(K)$ & $K_{\text {D }}\left(\mathbf{M}^{-1}\right)$ & $k_{B}\left(\mathbf{M}^{-1} s^{-1}\right)$ & $R^{2}$ \\
\hline 295 & 969 & $969 \times 10^{-8}$ & 0.9 \\
303 & 664 & $664 \times 10^{-8}$ & 0.9 \\
310 & 565 & $565 \times 10^{-8}$ & 0.9 \\
\hline
\end{tabular}

Table 3- Association constants and the number of binding sites for the $\mathrm{Hb}$ - formetanate interaction

\begin{tabular}{cccc}
\hline T/K & $\mathbf{K}_{\mathrm{a}}\left(\mathbf{M}^{-1}\right)$ & $\mathbf{n}$ & $\mathbf{R}^{2}$ \\
\hline 295 & 8.6 & 0.37 & 0.96 \\
303 & 6.1 & 0.4 & 0.97 \\
310 & 6.7 & 0.5 & 0.94 \\
\hline
\end{tabular}

Table 4- Thermodynamic parameters for the Hb-formetanate interaction at different temperatures

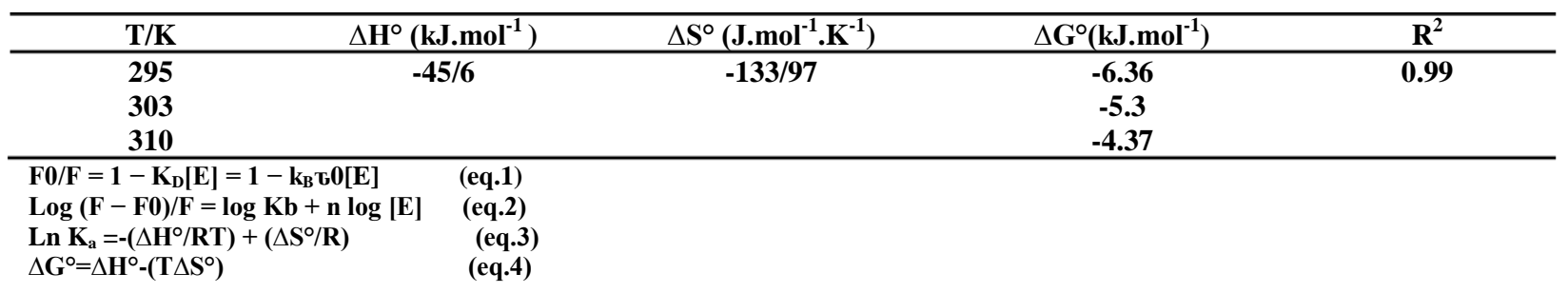


Figure 7 shows the $\mathrm{CD}$ spectra of $\mathrm{Hb}$ and $\mathrm{Hb}-$ formetanate hydrochloride complex. In the far UV-CD spectrum, we observed two negative peaks at 208 and $222 \mathrm{~nm}$ that related to $\pi \rightarrow \pi^{*}$ transition in $\alpha$-helix and $n \rightarrow \pi^{*}$ transition in both $\alpha$-helix and random coil, respectively. Loss of helicity was evident when the concentration of insecticide was raised. The association constant and the number of binding sites were obtained at three different temperatures $(295,303$ and $310 \mathrm{~K})$ from the slops of the $\log \left(\mathrm{F}-\mathrm{F}_{0}\right) / \mathrm{F}$ versus $\log [\mathrm{Q}]$ plots (eq.2). As temperature increased, the binding constants reduced due to destabilization of the $\mathrm{Hb}$-formetanate hydrochloride complex. It should be noted that unlike $\mathrm{K}_{\mathrm{D}}$, high temperature has a negative effect on $\mathrm{K}_{\mathrm{a}}$ and decreases stability of complexes. The number of binding sites was found to be 0.5 , indicating a 1:2 ratio between hemoglobin and formatanate hydrochloride during the binding process.
Table 4 represents the thermodynamic parameters for the interaction of formetanate hydrochloride with $\mathrm{Hb}$ at different temperatures.

According to molecular docking results, although formatanate hydrochloride could attach to both $\mathrm{Hb}$ central cavity and the hydrophobic pocket, the docking energy for binding of formatanate hydrochloride to the hydrophobic pocket $(-100 / 518)$ is slightly greater than that for binding to the central cavity (-83/875). Figure 8 displays the most favorable binding sites for formatanate hydrochloride in the hydrophobic pocket of $\mathrm{Hb}$. In this region, formetanate hydrochloride is located near the hydrophobic residues (such as Ala, Trp and Pro) and can easily interact with the prosthetic heme group. This observation is in agreement with the results obtained from Uv-Vis and fluorescence spectroscopy and heme degradation study

Figure 6- Fluorescence spectra of heme degradation products at $\lambda_{\mathrm{ex}}=321 \mathrm{~nm}$ (A) and $\lambda_{\mathrm{ex}}=460 \mathrm{~nm}(\mathrm{~B})$, with increasing formetanate concentration $(\mathrm{pH}=7.4$ and $295 \mathrm{~K})$.

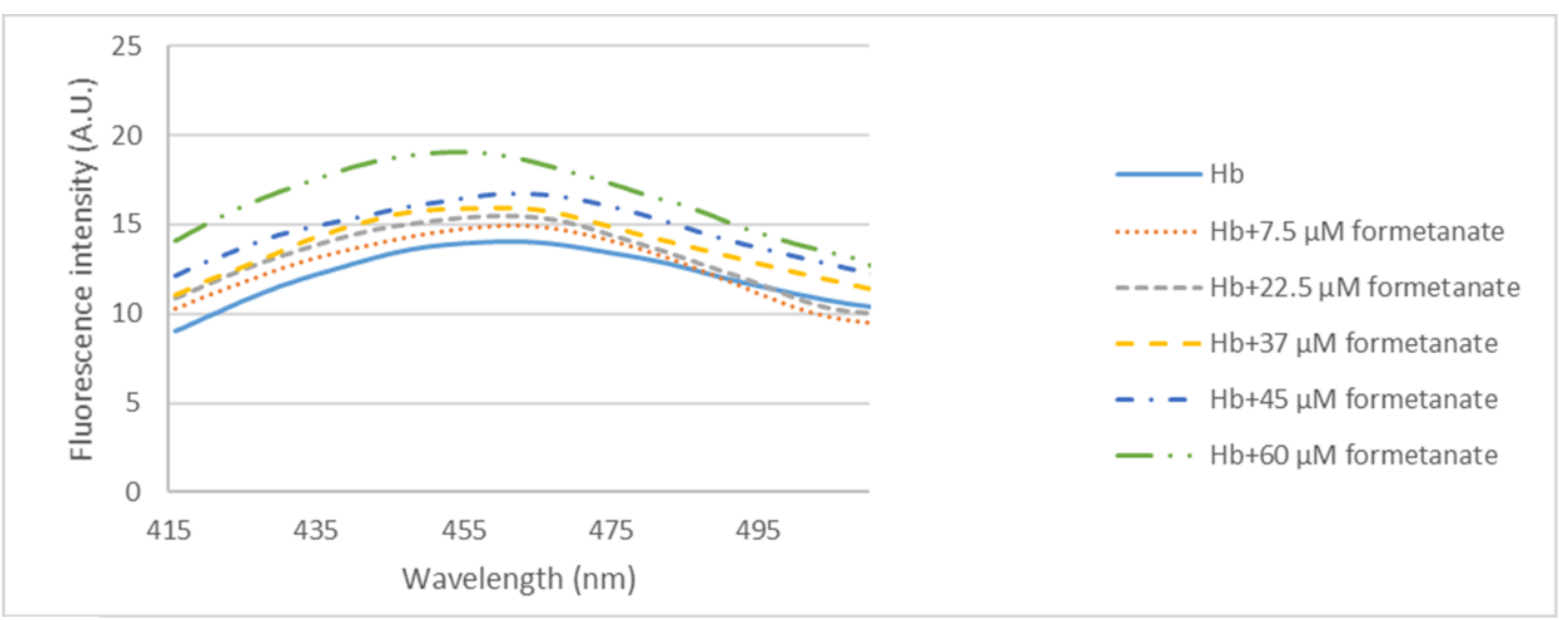

A

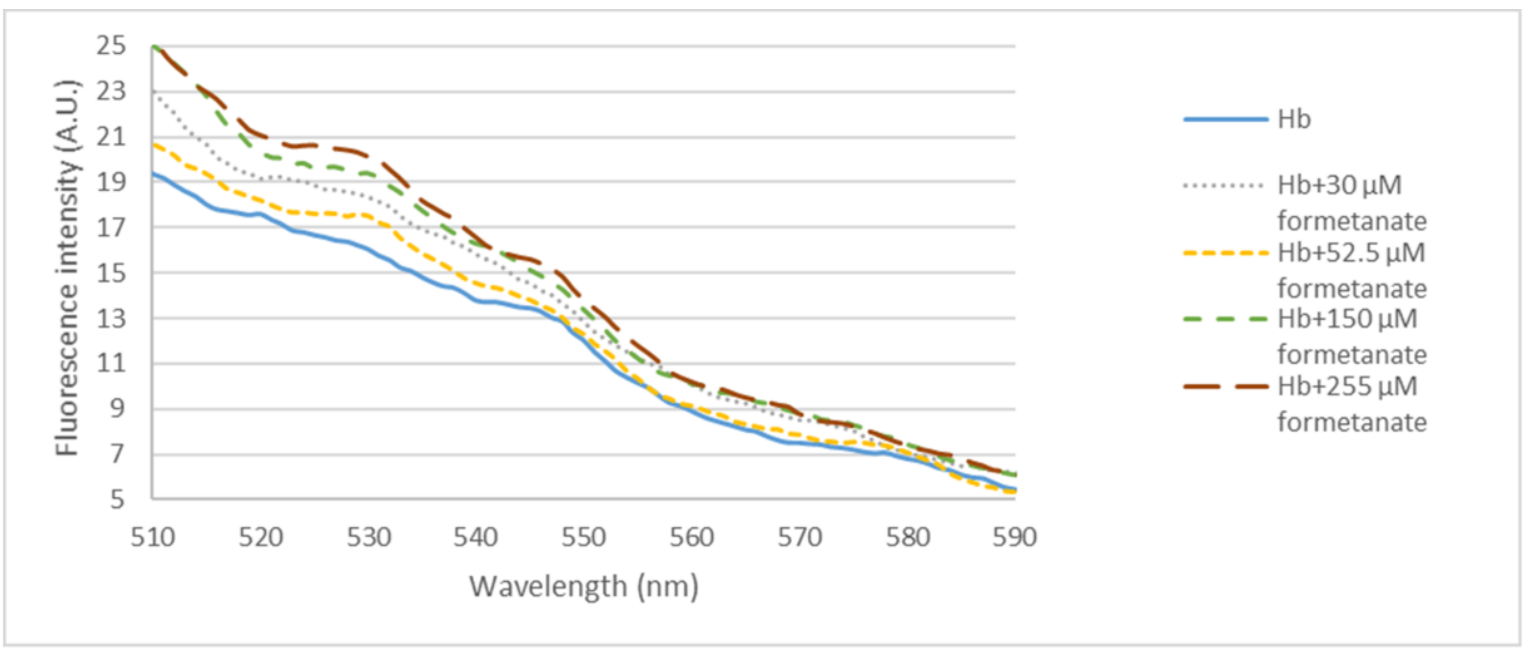


Figure 7- The far UV-CD spectra of $\mathrm{Hb}$ before and after the addition of formetanate (at $25^{\circ} \mathrm{C}$ and $\mathrm{pH} 7.4$ )

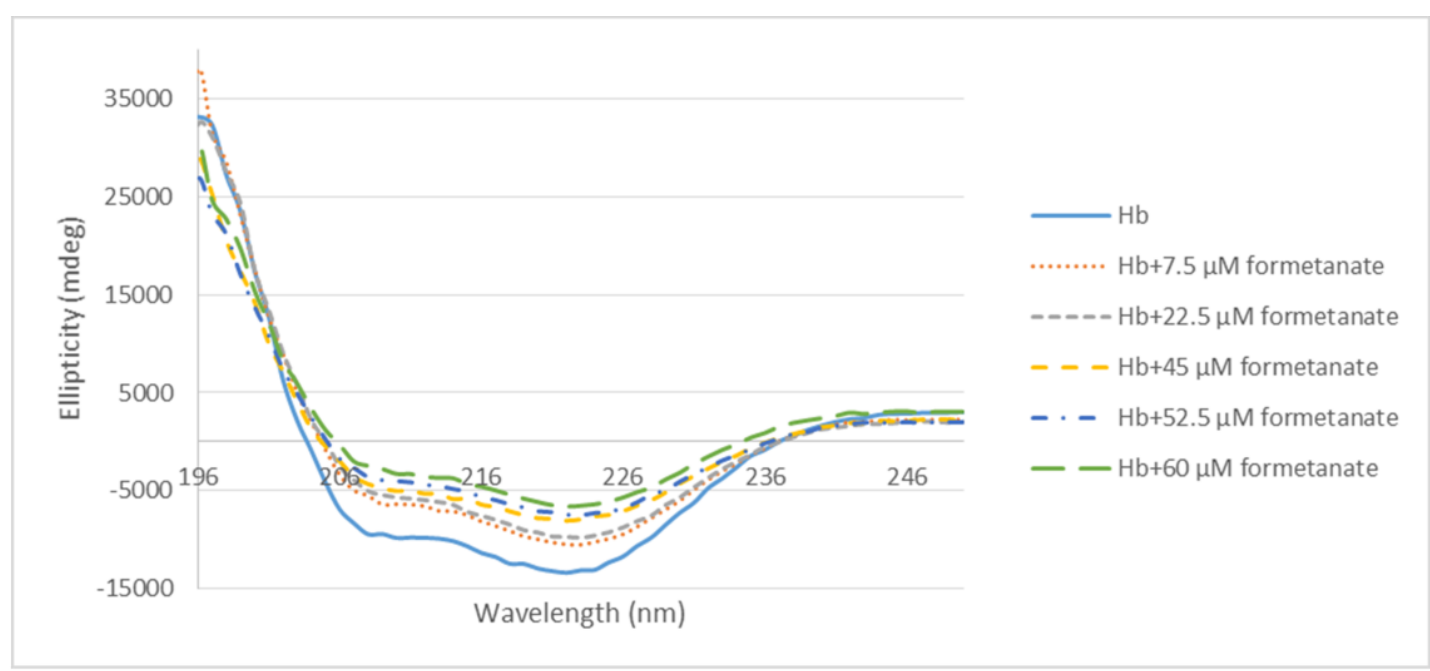

\section{DISCUSSION}

The absorbance decrement at $275 \mathrm{~nm}$ that arises from aromatic amino acids such as Trp, Thy and Phe demonstrated the occurrence of an interaction between $\mathrm{Hb}$ and formetanate hydrochloride (9). Decrement of the oxyHb related peaks at 541 and $577 \mathrm{~nm}$ stipulates the degradation of the heme prosthetic group, which impairs functionality in the active sites and reduces $\mathrm{Hb}$ oxygen affinity $(11,12)$. The results of protein aggregation study elucidated that formetanate hydrochloride could aggregate $\mathrm{Hb}$. A thermal aggregation curve comprises of three parts: a lag phase (representing duration of resistance against thermal aggregation), a logarithmic phase (where the protein starts unfolding) and a plateau phase (in which the protein is fully destroyed) (13). A more stable protein has a larger lag phase and its logarithmic phase has a slow slope (12-14). As mentioned previously, hydrophobic interactions have a main role in the formetanate hydrochloride- $\mathrm{Hb}$ interaction and protein denaturation. Therefore, the possibility of aggregation was enhanced by the increased hydrophobic forces on the $\mathrm{Hb}$ surface resulting from increasing concentrations of formetanate hydrochloride.

The hem prosthetic group is able to interfere in the emission spectrum of aromatic residues at high $\mathrm{Hb}$ concentrations. In other words, heme-filtering phenomenon is responsible for $99 \%$ of non-radiative quenching of aromatic fluorophores emission (15-17). Incremental course of emission intensity could be explained by the heme degradation process and termination of its filtering effect $(18,19)$.

Alteration in the polarity around aromatic residues was related to displacement of the maximum peaks towards the longer wavelengths. As explained previously, the interaction between formetanate hydrochloride and $\mathrm{Hb}$ exposes hydrophobic patches on protein surfaces to the solvent (20).

Reduction of the CD intensity in the presence of formetanate hydrochloride elucidated that the insecticide may be able to induce conformational changes in the secondary structure of $\mathrm{Hb}(21,22)$

Based on the results of thermodynamic parameters and the negative values of both $\Delta \mathrm{H}^{\circ}$ and $\Delta \mathrm{S}^{\circ}$, it can be concluded that the binding process is enthalpy driven and the hydrogen bonds and van der Waals forces are involved in the binding reaction and complex stability. In addition, the negative amount of $\Delta \mathrm{G}^{\circ}$ confirms that the binding process is spontaneous (23).

\section{CONCLUSION}

Our findings demonstrate that formetanate hydrochloride can cause conformational changes in the human $\mathrm{Hb}$. Higher affinity of formetanate hydrochloride to penetrate the hydrophobic pocket results in heme destruction and elimination of heme filtering group.

Furthermore, the competitive behavior of this insecticide for the oxygen site can subsequently reduce the oxy form of $\mathrm{Hb}$. 


\section{ACKNOWLEDGMENTS}

The authors gratefully acknowledge the financial support from the Research Council of the Alzahra University, Iran.

\section{REFERENCES}

1. Perut M. Mechanisms regulating the reactions of human hemoglobin with oxygen and carbon monoxide. Annu Rev Physiol. 1990; 52(1): 1-25.

2. White JM. Hemoglobin structure and function: its relevance to biochemistry and medicine. Molec Aspects Med. 1977; 1(2): 129-185.

3. Shaana B. Structure of Human Oxyhaemoglobin at 2/1 ${ }^{\circ}$ Resolution. J Mol Biol. 1983; 171(1): 31-59.

4. Basu A, Kumar GS. Interaction of toxic azo dyes with heme protein: Biophysical insights into the binding aspect of the food additive amaranth with human hemoglobin. Journal of Hazardous Materials. 2015; 289 : 204-209.

5. Divito $\mathrm{CB}$, Davies S, Masoudi S, Muhoro $\mathrm{CN}$. Relative Stability of Formamidine and Carbamate Groups in the Bifunctional Pesticide Formetanate Hydrochloride. J Agric Food Chem. 2007; 55(14): 53775382. DOI: 10.1021/jf0637527.

6. Baron RL. A carbamate insecticide: a case study of aldicarb. EnViron Health Perspect. 1994; 102(suppl.11): 23-27. doi: 10.1289/ehp.94102s1123.

7. Wolfe NL, Zepp RG, Paris DF. Use of structurereactivity relationships to estimate hydrolytic persistence of carbamate pesticides. Water Res. 1978; 12(8): 561563. DOI: 10.1016/0043-1354(78)90133-1.

8. Liu W, Ding F, Sun Y. Characterization of Phenosafranine-Hemoglobin Interactions in Aqueous Solution. J Solution Chem. 2011; 40(2): 231-246.

9. Rafiei J, Yavari K, Moosavi-Movahedi AA. Preferential Role of Iron in Heme Degradation of Hemoglobin upon Gamma Irradiation. Int $\mathrm{J}$ Biol Macromol. 2017; 103: 1087-1095. doi: 10.1016/j.ijbiomac.2017.05.153.

10. Khatibi A, Keihan AH, Sheikh Hasani V. Bio thermodynamic studies of diclofenac interaction with lysozyme under various conditions using diclofenacselective membrane electrode. J. Biomolecular Structure and Dynamics. 2017; 35(13): 2789-2793.

11 Li DJ, Zhu JF, Jin J, Yao XJ. Studies on the binding of nevadensin to human serum albumin by molecular spectroscopy and modeling. J Mol Struct. 2007; 846(13): 34-41.

12. Hosseinzadeh R, Moosavi-Movahedi AA. Human hemoglobin structural and functional alterations and heme degradation upon interaction with benzene: A spectroscopic study. Spectrochim Acta A Mol Biomol Spectrosc. 2016; 157: 41-49. doi: 10.1016/j.saa.2015.12.014.

\section{CONFLICTS OF INTEREST}

There is no conflict of interest regarding publication of this article.

13. Najdegerami IH, Maghami $P$, Sheikh-Hasani V, Hosseinzadeh G, Sheibani N, Moosavi-Movahedi AA. Antichaperone activity and heme degradation effect of methyl tert-butyl ether (MTBE) on normal and diabetic hemoglobins. J Mol Recognit. 2017; 30(5). doi: 10.1002/jmr.2596.

14. Khan MS, Tabrez S, Bhat SA, Rabbani N, AlSenaidy AM, Bano B. Effect of trifluoroethanol on $\alpha$ crystallin: folding, aggregation, amyloid, and

cytotoxicity analysis. J. Mol. Recognit. 2016; 29(1): 3340.

15. Fang X, Cao S, Liu R. Interaction of Bisphenol A with Bovine Hemoglobin Using Spectroscopic and Molecular Modeling Methods. Appl Spectrosc. 2011; 65(11): 1250-3. doi: 10.1366/11-06357.

16. Maity S, Chakraborty S, Chakraborti AS. Critical insight into the interaction of naringenin with human haemoglobin: A combined spectroscopic and computational modeling approaches. J Mol Struct. 2017; 1129: 256-262.

17. Nagababu A, Rifkind JM. Formation of Fluorescent Heme Degradation Products during the oxidation of Hemoglobin by Hydrogen Peroxide. Biochem Biophys Res Commun. 1998; 247(3): 592-596.

18. Wang L, Liu R, Chi Z, Yang B, Zhang P, Wang M. Spectroscopic investigation on the toxic interactions of $\mathrm{Ni}$ with bovine hemoglobin. Spectrochim Acta A Mol Biomol Spectrosc. 2010; 76(2): 155-160.

19. Hirstch R. Hemoglobin Fluorescence. In: Hemoglobin disorders: molecular methods and protocols. United States: Humana Press: 2003.

20. Subramanyam R, Goud M, Sudhamalla B, Reddeem E, Gollapudi A, Nellaepalli S. Novel binding studies of human serum albumin with trans-feruloyl maslinic acid. J Photochem Photobiol B. 2009; 95(2): 81-8. doi: 10.1016/j.jphotobiol.2009.01.002.

21. Lu JQ, Jin F, Sun TQ, Zhou XW. Multispectroscopic study on interaction of bovine serum albumin with lomefloxacin-copper(II) complex. Int J Biol Macromol. 2007; 40(4): 299-304.

22. Xiao M, Yuan X, Xie W, Ge X, Zhou Y. Comparison of 9-hydroxy-artemisinin with artemisinin: interaction with bovinehemoglobin. J Lumin. 2015; 160: 188-194. DOI: 10.1016/j.jlumin.2014.12.002

23. Wu X, Liu J, Wang Q, Xue W, Yao X, Zhang Y, Jin J. Spectroscopic and molecular modeling evidence of clozapine binding to human serum albumin at subdomain IIA. Spectrochim Acta A Mol Biomol Spectrosc. 2011; 79(5): 1202-9. doi: 10.1016/j.saa.2011.04.043. 